\title{
Spanish scientific output on Helicobacter pylori. A study through Medline
}

\author{
M. Trapero-Marugán, J. P. Gisbert and J. M. Pajares \\ Service of Digestive Diseases. Hospital Universitario de La Princesa. Madrid, Spain
}

\begin{abstract}
Objectives: to analyze scientific output from Spanish hospitals in relation to Helicobacter pylori infection.

Methods: papers collected from the Medline database between January 1988 and December 2003 were selected. Our search strategy was: "Helicobacter pylori" [MeSH] AND ((Spain [AD] OR Espana [AD] OR Spanien [AD] OR Espagne [AD] OR Espanha [AD]) OR (Spanish [LA]) OR Spain). The following was analyzed: geographic area, Spanish or foreign publication, topic, and year of publication. Output and impact bibliometric markers were evaluated.

Results: in all, 691 papers were identified, of which 241 were excluded. Number of papers went from 2 in 1988 to 47 in 2002 and 13 in 2003. There were more reports in Spanish versus foreign journals (58 vs. 42\%). In the first 5 years the areas with greater output were associated with diagnosis and microbiology (33 and 20\%), whereas therapy was the predominating subject during the last 5 years (27\%). Original papers were most common among publications (69\%). Hospitals with highest output included La Princesa (24\%) and Ramón y Cajal (17.6\%) in Madrid, and Parc Taulí in Barcelona (6.4\%). Mean impact factor progressively increased from 1.826 in 1988 to 2.142 in 2002 and 2.493 in 2003.

Conclusions: the production and impact of documents published by Spanish scientists regarding $H$. pylori infection considerably increased during the past two decades.
\end{abstract}

Key words: Helicobacter pylori. Spain. Scientific information.

Trapero-Marugán M, Gisbert JP, Pajares JM. Spanish scientific output on Helicobacter pylori. A study through Medline. Rev Esp Enferm Dig 2006; 98: 255-264.

Recibido: 09-01-04.

Aceptado: 17-02-04.

Correspondencia: Javier P. Gisbert. Servicio de Aparato Digestivo. Hospital Universitario de La Princesa. C/ Diego de León, 62. 28006 Madrid. Fax: 914022 299. e-mail: gisbert@meditex.es

\section{INTRODUCTION}

Medline, the database most widely used by medicine practitioners, includes almost 4,000 journals, 35 of which are published in Spain (1-4). Bibliometric studies have been ongoing for more than twenty years in order to assess the scientific activities of professionals in the various scientific settings. In the medical setting numerous studies analyze the production, circulation, spread, and impact of publications in the various fields of specialization (5-11).

Helicobacter pylori (H. pylori) was initially identified in 1992 (12), and was subsequently shown to be the etiologic agent responsible for most gastritis and gastroduodenal ulcer cases (13), as well as an essential factor for the development of gastric cancer (14). Following the characterization of $H$. pylori numerous investigators, including Spanish researchers, began their reports on this new bacterium. H. pylori infection represents a significant public health challenge because of its high prevalence, potential for ulcerative complications (especially gastrointestinal bleeding), and potential risk for gastric adenocarcinoma or lymphoma development (15). These determinants represented a relevant scientific drive, and entailed the adoption of numerous resources for the investigation of $H$. pylori infection and its consequences. As with other diseases, the number of reports related to $H$. pylori has progressively increased over the last few decades, and areas of report have evolved according to knowledge gained.

Following a review of the literature, no study has assessed publications by Spanish authors regarding $H$. pylori infection yet. Therefore, the goal of this study was to analyze the scientific output of Spanish professionals on $H$. pylori in national institutions, from early 1988 to August 2003. To this end, bibliographic references in the Medline database were evaluated. 


\section{PATIENTS AND METHODS}

Documents classified as original papers, clinical reports, letters, editorials, and reviews of publications included in Medline from 1988 to December 2003 were analyzed using the PubMed search engine. For this search we based ourselves on a previously published paper on Spanish scientific output regarding human immunodeficiency virus (6).

\section{Search strategy}

Our search strategy was based on two fields: MeSH (Medical Subject Headings) and AD (Affiliation).

1. To find publications on H. pylori the term "Helicobacter pylori" [MeSH] was used in the MESH field.

2. To find Spanish publications, that is, publications where the first undersigned was of Spanish nationality, the following terms were used in the AD field: ((Spain [AD] OR Espana [AD] OR Spanien [AD] OR Espagne [AD] OR Espanha [AD]) OR (Spanish [LA]) OR Spain).

3. Therefore, the overall strategy was as follows: "Helicobacter pylori" [MeSH] AND ((Spain [AD] OR Espana [AD] OR Spanien [AD] OR Espagne [AD] OR Espanha $[\mathrm{AD}])$ OR (Spanish [LA]) OR Spain).

\section{Exclusion criteria}

1. Papers with a PT (Publication Type) field containing: letter, editorial, carta, or news.

2. Papers including $H$. pylori infection as an exclusion criterion.

3. Works by Spanish authors in foreign centers, or with non-Spanish authors.

4. Papers with "Port of Spain" in the AD field.

\section{Data collection}

The following data were collected from all papers: a) journal nationality; b) paper language; c) paper type, according to three categories: clinical report (letter, news or editorial), review or original article (those not included in the former two); d) journal title; e) journal impact factor [according to JCR (Journal Citation Report) for 2001]; f) paper publication year; g) first undersigned's center or institution; $h$ ) center's province and Autonomous Community; i) exclusion criteria; and j) topic area (see the following section).

\section{Topic areas}

1. Epidemiology, transmission and prevention of $H$. pylori infection; prevalence studies for geographic areas were included.
2. Microbiology and immunology.

3. Dyspepsia.

4. Ulcer and complications (bleeding, stenosis, perforation).

5. Gastric neoplasms (adenocarcinoma and lymphoma).

6. Diagnostic methods: histologic, microbiologic, immunologic and molecular.

7. Treatment: all drug duration and dosage variations are included. Treatment adverse effects.

8. Extra-gastrointestinal manifestations of $H$. pylori infection.

9. Other topics not included in any of the previous sections.

\section{Statistical analysis}

Data collected were recorded in a database developed to this end, and statically analyzed using the SPSS 11.0 for Windows program (SPSS Inc, Illinois, USA). For quantitative variables mean and standard deviation (SD) values were estimated, as was percentage for qualitative variables.

\section{RESULTS}

\section{Excluded documents}

Using the search strategy described in the Methods section 691 documents were initially identified, 241 of which were excluded. Reasons for exclusion are listed in table I. Of 241 documents excluded, $83 \%$ had been published in national journals, and $17 \%$ in foreign journals. Most common among excluded documents were original papers $(44 \%)$, followed by clinical notes (40\%). Most common among reasons for exclusion was the author's foreign nationality $(64 \%)$. The journal with a higher number of excluded publications was Acta Gastroenterológica Latinoamericana, for a total of 40 documents (17\%).

Table I. Reasons for the exclusion of papers initially identified by our search strategy

\begin{tabular}{lc}
\hline Reason & Number \\
\hline $\begin{array}{l}\text { Documents with PT including: "Letter", "Editorial", } \\
\text { "News" or "Carta" }\end{array}$ & $75(31 \%)$ \\
$\begin{array}{l}\text { Documents where H. pylori infection was an exclusion } \\
\text { criterion }\end{array}$ & $0(0 \%)$ \\
Documents from foreign centers & $157(65 \%)$ \\
Documents unrelated to H. pylori & $9(3.7 \%)$ \\
\hline Total & $241(100 \%)$ \\
\hline PT: Publication Type (MedLine field identifying documents by publication type).
\end{tabular}


Table II. First five national and foreign journals with the highest number of papers on $H$. pylori

\begin{tabular}{lclc}
\hline National journal & No. documents & Foreign journal & No. documents \\
\hline Rev Esp Enferm Dig & $61(14.1 \%)$ & Aliment Pharmacol Ther & $24(5.4 \%)$ \\
Gastroenterol Hepatol & $39(9 \%)$ & Eur J Gastroenterol Hepatol & $19(4.4 \%)$ \\
Med Clin (Barc) & $35(8.1 \%)$ & Am J Gastroenterol & $13(3 \%)$ \\
Enferm Infecc Microbiol Clin & $28(6.5 \%)$ & Helicobacter & $9(2 \%)$ \\
Rev Clin Esp & $22(5.1 \%)$ & Scand J Gastroenterol & $9(2 \%)$ \\
\hline
\end{tabular}

Percentage refers to total of analyzed documents (national plus foreign).

\section{Journal type}

The scientific output of Spanish authors spread across 93 journals: 58\% were Spanish, $42 \%$ were nonSpanish. Table II shows the 10 journals with more papers identified $-42 \%$ of documents were published by the 5 Spanish journals with higher print runs. Regarding foreign journals, all 5 with higher print runs included $17 \%$ of total publications.

\section{Document type}

The predominating document type was the original paper, for a total of 311 articles (69\%), followed by reviews $-123(27 \%)-$ and clinical notes -16 (3.6\%). The chronologic evolution of document types was different during the first five years versus the last five years, as can be seen in figure 1 . Original papers were most common both in the initial $(74 \%)$ and the last 5 years $(69 \%)$. Reviews percentage remained stable for the first and last five years (26 and 28\%, respectively); and clinical notes increased by 1988 (0\% during the 80 s versus $3.8 \%$ for the last five years).

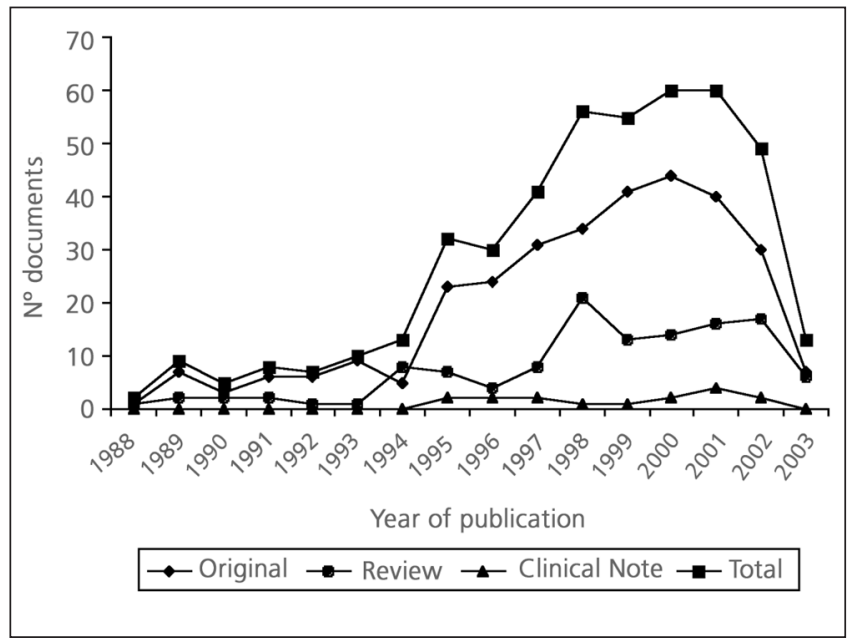

Fig. 1.- Evolution of papers published over time.

Evolución cronológica del tipo de documento publicado.

\section{Bibliometric production and impact indicators}

Figure 1 shows the chronological evolution of publication output over the years. In 19882 papers on H. pylori were published, whereas in 2002 Spanish authors published 42 papers, plus 13 documents in 2003. The growth pattern of scientific output follows an abnormal distribution, being rather asymmetric with an irregular ascending phase peaking in 2000 and 2001, and a subsequent decline in 2002 and 2003.

Table III. Eight Spanish centers with the highest mean impact factor

\begin{tabular}{lc}
\hline Institution & $I F \pm S D$ \\
\hline Hospital Ntra. Sra. de Aránzazu, San Sebastián & $5.39 \pm 5.4$ \\
Hospital Clínic, Barcelona & $5.25 \pm 4.9$ \\
Hospital Lozano Blesa, Saragossa & $3.86 \pm 3.9$ \\
Hospital Mutua de Terrasa, Barcelona & $3.55 \pm 0$ \\
Hospital Parc Taulí, Barcelona & $2.95 \pm 1.4$ \\
Hospital de La Princesa, Madrid & $1.7 \pm 1.2$ \\
Hospital La Fe, Valencia & $1.34 \pm 1.3$ \\
Hospital Ramón y Cajal, Madrid & $1.12 \pm 1.7$ \\
\hline
\end{tabular}

IF: Impact factor. SD: Standard deviation.

The impact of Spanish scientific output on H. pylori infection as a whole has also increased over the years (Fig. 2). Mean overall impact factor was $1.95 \pm 2$. Mean impact factor for 1988 was $1.82 \pm 0$, and increased to $2.49 \pm 1.4$ by 2003 . According to Centers, the highest mean IF corresponded to Nuestra Señora de Aránzazu Hospital (Guipúzcoa), with a mean IF of $5.39 \pm 5.4$. Regarding Autonomous Communities, those with a higher mean IF were the Basque Country $(3.89 \pm 4)$, Catalonia (3.14 \pm 2.6$)$, and Aragon (2.9 \pm 3.2$)$.

\section{Topic areas}

Among the total 449 documents collected and included, $123(27 \%)$ were related to $H$. pylori infection therapy. These were followed by 79 papers $(18 \%)$ on diagnostic methods, $67(15 \%)$ on bacteriologic, genetic, and immunologic issues, 42 (9.4\%) on extra-gastrointestinal manifestations, $39(8.7 \%)$ on ulcer and related complications, and 


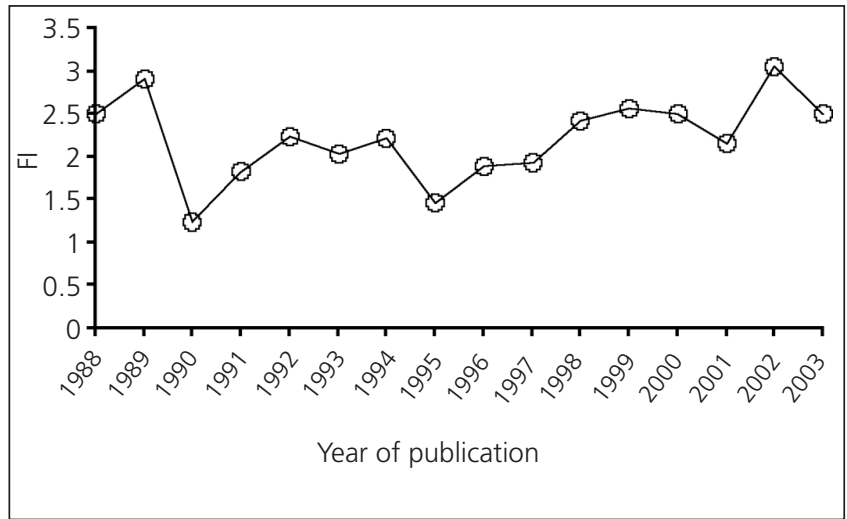

Fig. 2.- Evolution of mean impact factor (IF) over time. Evolución cronológica del factor de impacto (FI) medio.

$34(7.6 \%)$ on dyspepsia. Topic areas with a highest output included: therapy, diagnostic methods/bacteriology, genetics, and immunology. From 1996 on the microbiology topic area considerably declined, whereas therapy accounted for the majority of scientific output.

\section{Institutions}

The center with the highest amount of publications was Hospital de La Princesa, Madrid, with a total of 108 (24\%). Table IV lists all 8 centers with a higher amount of papers. The number of papers published varied over follow-up time; thus, centers such as Hospital de La Princesa, Madrid, Parc Taulí, Barcelona, and Lozano Blesa, Saragossa, increased their scientific output over the last 5 years, while centers such as Hospital Ramón y Cajal or La Paz, both in Madrid, or Nuestra Señora de Aránzazu, in Guipúzcoa, declined during the latter period.

Table IV. Eight Spanish centers with the highest number of papers

\begin{tabular}{lc}
\hline Institution & $\begin{array}{c}\text { No. of publications } \\
\text { (\% of total) }\end{array}$ \\
\hline Hospital de La Princesa, Madrid & $108(24.1 \%)$ \\
Hospital Ramón y Cajal, Madrid & $79(17.6 \%)$ \\
Hospital Parc Taulí, Barcelona & $29(6.4 \%)$ \\
Hospital Lozano Blesa, Saragossa & $20(4.5 \%)$ \\
Hospital Clínic, Barcelona & $15(3.3 \%)$ \\
Hospital Miguel Servet, Saragossa & $13(3 \%)$ \\
Hospital La Paz, Madrid & $9(2 \%)$ \\
Hospital Ntra. Sra. Aránzazu, San Sebastián & $8(1.8 \%)$ \\
\hline
\end{tabular}

\section{Autonomous Community and Province}

Regarding geographic origin, Autonomous Communities with a higher number of publications included
Madrid with 215 papers (48\%), Catalonia with 89 (20\%), Aragon with 39 (8.7\%), Andalusia with 25 (5.6\%), and the Basque Country with 13 (2.9\%). By province, Madrid was most prolific with 215 (48\%), followed by Barcelona with $84(19 \%)$ and Saragossa with $35(7.8 \%)$.

\section{DISCUSSION}

For more than two decades now bibliometric studies have been performed to assess professionals' scientific output in various scientific settings. While numerous studies discuss paper production, circulation, spread, and impact in a number of specialties, no single study has ever assessed publications by Spanish authors on $H$. pylori infection. The relevance of this organism, which was first isolated some two decades ago, results from its etiologic role in various gastroduodenal conditions, including chronic gastritis, peptic ulcer, and gastric cancer.

Thus, we deemed it interesting to analyze scientific output on $H$. pylori by Spanish professionals in national institutions from early 1988 to this day by evaluating bibliography references included in the Medline database. A progressive increase in overall Spanish scientific production has been seen since the 1980's, which also involves Gastroenterology. As H. pylori was first isolated only a few years ago, this is a field where chronologic changes in publication numbers can be most clearly identified. Thus, only two papers were published on $H$. pylori in 1988, whereas 42 papers by Spanish authors saw the light in 2002. From a different standpoint, mean impact factor was 1.82 in 1988, and had increased to 2.49 by 2003 .

Number of publications grew initially until 2000 and 2001, and then declined in 2002 and 2003; such descending trend may reflect an actual decrease in Spanish scientific output, but this needs confirmation in the next few years. Nevertheless, explanations for decreased publication numbers in a given scientific field may be diverse; thus, for instance, difficulties in performing further quality, novel, and increasingly complex studies after an initial, truly explosive publishing phase may considerably restrict scientific output. In this respect, while topic areas with a higher output included therapy, diagnostic methods and bacteriology, genetics, and immunology, microbiology was seen to considerably decline starting in 1996, whereas therapy monopolized most scientific production. On the other hand, Healthcare research budgets have been decreased and, while the quality of scientific production by Spanish investigators keeps growing (as reflected by the increasing mean impact factor of publications), a decrease in scientific output is to be expected following the restricted research project numbers.

As occurs with other specialties, the Autonomous Communities of Madrid and Catalonia are responsible for most National scientific production. Regarding $H$. pylori infection, almost one half of papers were from Madrid, while Barcelona accounted for $20 \%$ of publica- 
tions. While both Autonomous Communities have substantial R\&D budgets, in addition to greater numbers of institutions and hospitals, the fact that scientific output was concentrated almost exclusively in two centers in Madrid (Hospitals La Princesa and Ramón y Cajal) and two centers in Barcelona (Hospitals Parc Taulí and Clínic) should be highlighted. These findings underscore the importance of "local" research groups with a specific focus on $H$. pylori infection.

The mean impact factor of Spanish publications on $H$. pylori was 1.95 , which represents a figure above those of other medical fields, including respiratory system (5), HIV infection (6), nutrition (7), substance abuse (8), pharmacy (9), and rheumatology (10). However, there is a number of specialties, including neuroscience, where publications have a higher mean impact factor (11) when compared to gastroenterology.

This study has, however, some limitations. First, bibliometric studies have a number of restrictions, as they are based on documents from an information collection database such as Medline containing biases. Medline was selected for being most widely used by both Spanish and foreign physicians, for including not only indexed journals with an impact factor on the Science Citation Index (SCI), but also less relevant papers, and for being easily accessible (1-4). This database has been used for bibliometric studies in other medical areas regarding scientific output by Spanish authors (5-11). A further Medline limitation is that it does not include full data on documents classified as clinical notes or editorials, but this bias was corrected by excluding such papers from the study. Finally, we may have missed a number of papers by Spanish authors not included as first undersigned, as Medline only includes demographic data the latter group.

In summary, findings in the present study demonstrate that the production and impact of documents published by Spanish authors regarding $H$. pylori infection have considerably increased during the last two decades. A greater quality has also been attained, with papers having a higher mean impact factor. Autonomous Communities with the highest output and impact rates still include Madrid and Catalonia. Regarding topic area, therapy is most relevant nowadays, in contrast to diagnosis and microbiology, which were more significant in initial years.

\section{ACKNOWLEDGMENTS}

This study was partly supported by a grant from Instituto de Salud Carlos III (C03/02).

\section{REFERENCES}

1. Simó Miñana J, Gaztambide Ganuza M, Latour Pérez J. Producción científica de los profesionales españoles de atención primaria (19901997). Un análisis bibliométrico a partir de MedLine. Aten Primaria 1999; 52: 751-4.

2. Osca J. Producción bibliográfica española sobre el sida. Acercamiento bibliométrico. Enferm Infecc Microbiol Clin 1997; 15: 407-10.

3. Pestaña A. El Medline como fuente de información bibliométrica de la producción española en biomedicina y ciencias médicas. Comparación con el Science Citation Index. Med Clin (Barc) 1997; 109: 50611.

4. Camí J, Fernández MT, Gómez Caridad I. La producción científica española en biomedicina y ciencias de la salud. Un estudio a través del Science Citation Index (SCI) 1986-1989. Med Clin (Barc) 1993; 101: 721-31.

5. García Río F, Álvarez-Sala R, Gómez Mendieta MA, Ruiz Peña A, Serrano Peña S, Pino García JM, et al. Evolución de la producción científica española en revistas internacionales de sistema respiratorio de 1987 a 1998. Med Clin (Barc) 2000; 115: 287-93.

6. Ramos Rincón JM, Belinchón Romero I, Gutiérrez Rodero F. La producción científica española respecto a la infección por el virus de la inmunodeficiencia humana/sida. Un estudio a través de MedLine (1991-1999). Med Clin (Barc) 2001; 117: 645-53.

7. Barenys M, Recasens MA, Camps J, Salas J. La producción científica española sobre alimentación y nutrición de 1987 a 1990. Med Clin (Barc) 1992; 99: 9-12.

8. Guardiola E, Sánchez Carbonell J. Análisis de la producción científica española en dependencia a drogas. Med Clin (Barc) 1992; 101: 36871.

9. Bordons M, Barrigón S, Méndez A. La investigación española en revistas internacionales de farmacia y farmacología durante el período 1980-1989. Med Clin (Barc) 1996; 106: 51-9.

10. Batle-Gualda E, Trenor Larraz P, Noguera Pons R, Godoy Laserna C. Investigación en reumatología. Análisis de los documentos españoles publicados durante 1990-1996 en nueve revistas extranjeras de la especialidad. Rev Clin Esp 1998; 198: 587-95.

11. López-Muñoz F, Marín F, Boya J. Evaluación bibliométrica de la producción científica española en Neurociencia. Análisis de las publicaciones de difusión internacional durante el período 1984-1993. Rev Neurol 1996; 24: 417-26.

12. Marshall BJ, Warren JR. Unidentified curved bacilli in the stomach of patients with gastritis and peptic ulceration. Lancet 1984; 1: 1311-5.

13. Gisbert JP, Boixeda D, Martín de Argila C, García Plaza A. Helicobacter pylori y úlcera duodenal: ¿relación causal o mera asociación? Rev Clin Esp 1997; 197: 693-702.

14. Gisbert JP, Boixeda D, Martín de Argila C. ¿Es el cáncer gástrico una enfermedad infecciosa? Rev Esp Enferm Dig 1996; 88: 555-62.

15. Gisbert JP, Pajares JM. ¿Son todos los H. pylori malos? Rev Esp Enferm Dig 1999; 91: 508-15. 